\title{
A Proposal of General-Purpose Input Interface by Application of Horizon View Camera
}

\author{
Ayami Iwata Non-member (Gifu University, aya@yam.info.gifu-u.ac.jp) \\ Kunihito Kato Non-member (Gifu University, kkato@info.gifu-u.ac.jp) \\ Kazuhiko Yamamoto Member (Gifu University, yamamoto@info.gifu-u.ac.jp)
}

Keywords: Horizon View Camera. General-Purpose Input Interface, Portable Piano, Touch Sensor, Position Measurement

Now a day, many kinds of input interfaces have been proposed by physical sensors. With the developments of them, input interfaces by using a camera are researched actively. In the case of using the camera, there are a lot of advantages. It is possible to have various effective functions because the camera is a general-purpose sensor. Therefore, input interfaces with the camera have been proposed by various methods in a lot of fields. However, most of these methods measure only the position because the camera is usually set on the upper side. When we try to make the input interface as substitutes for a keyboard and a mouse, it is necessary to measure the position and detect the touch to the surface at the same time. In order to solve these problems, it is necessary to use some cameras generally.

We have proposed Horizon View Camera, we call it HVC. This is a unique camera system by using a camera and a mirror shown in fig. 1. It is possible to direct the optical axis of the camera to the horizon by reflection the mirror. Therefore, HVC can obtain two kinds of images shown in fig. 2. One is the image including only the object on the ground. Therefore, it is possible to detect objects easily. We have shown its effectiveness by measuring distances to

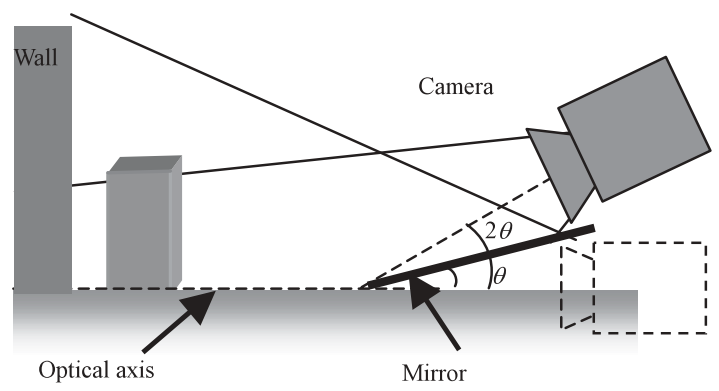

Fig. 1. HVC system

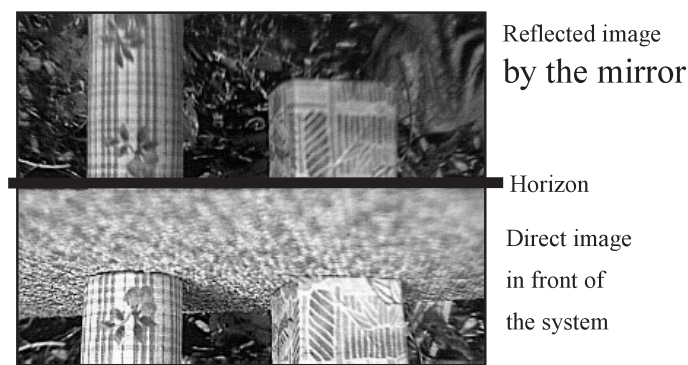

Fig. 2. Image from the HVC

objects using the obtained images from HVC with straight motions. Moreover, we proposed HVC-90 that is more effective system than the original HVC for object detection. HVC-90 can detect objects in various motions.

In these camera systems, we used characteristics obtained from moving HVC mainly. In this paper, we had second thoughts about these characteristics, consequently we obtained new characteristics. In the case of the input interface by using a camera, it is important to solve two considerations, the position measurement and the touch detection to the surface. By using new characteristics of HVC, however, these considerations can be solved.

Therefore, we propose a unique input interface by using characteristics of HVC. We have used images obtained by moving HVC to detect object. By focusing attention on images obtained by standing HVC, however, it is possible to realize a unique input interface with the position measurement and the touch detection. Moreover, we made Portable Piano as one example of this shown in fig. 3, and we show the effectiveness of this proposal system by the experiment.

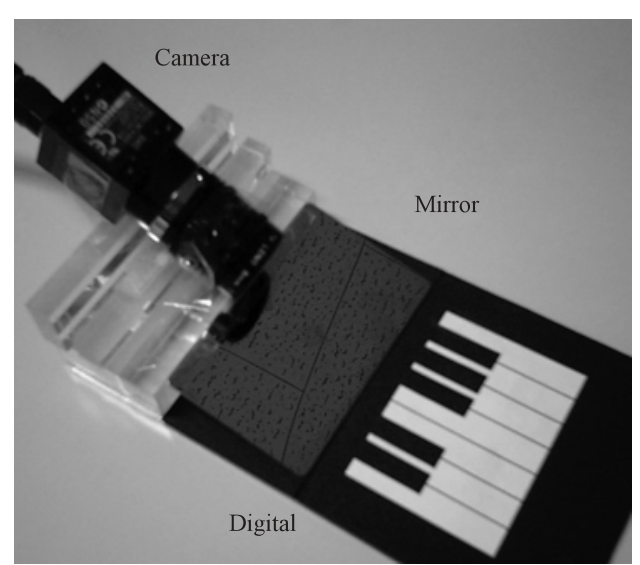

Fig. 3. Portable piano. 


\title{
Horizon View Camera の応用による汎用入力インターフェースの提案
}

\author{
非会員 岩田 彩見 ${ }^{*}$ 非会員 加藤 邦人* \\ 正 員 山本 和彦*
}

\section{A Proposal of General-Purpose Input Interface by Application of Horizon View Camera}

Ayami Iwata*, Non-member, Kunihito Kato*, Non-member, Kazuhiko Yamamoto*, Member

\begin{abstract}
We have proposed Horizon View Camera (HVC), which is a unique system of the object detection by a single camera and has some unique characteristics. HVC is to put a single camera on the ground, and the optical axis of the camera is directed toward the horizon by using a mirror. HVC can obtain two kinds of images. One is the image including only the object on the ground. Therefore, it is possible to detect objects easily. We have shown its effectiveness by measuring distances to objects using the obtained images from HVC with straight motions. Moreover, we proposed HVC-90 that is more effective system than the original HVC for object detection. HVC-90 can detect objects in various motions. In these camera systems, we used characteristics obtained from moving HVC mainly. In this paper, moreover, we develop a unique input interface by using characteristics from standing HVC. We made a potable piano as an example of this interface, and show its effectiveness.
\end{abstract}

キーワード : Horizon View Camera，汎用入カインターフェース，どこでもピアノ，タッチセンサー，位置計測

Keywords : Horizon View Camera, General-Purpose Input Interface, Portable Piano, Touch Sensor, Position Measurement

\section{1. はじめに}

現在，入力インターフェースとして各種センサーを用い たシステムが多く開発されているが(1)(2)，それに伴いカメラ を用いた入力インターフェースの研究も盛んに進められて いる(3) (5)。 カメラを用いることで， カメラの汎用的センサ 一としての利点を生かし, さらに多様な機能を持たせるこ とが可能であり，これまでにも幅広い分野において様々な 入力インターフェースが提案されている。しかし, これら カメラを用いた入力インターフェースの多くが, 上方にカ メラを設置するなどの方法による位置計測にとどまってい る。キーボードやマウスのようなインターフェースの代替 になるものを考えた場合，位置計測と平面への接触を同時 に検出する必要がある。これを実現するためには，一般的 にカメラを複数台用意する必要がある。

ところで, 我々は現在までに 1 台のカメラと鏡を用い, カメラの光軸を地平線上に走らせることで特殊な性質を持 たせた Horizon View Camera（以下，HVC）を提案してきた ${ }^{(6)}$ 。 HVC から得られる画像のうちの半分は, 鏡の反射画像で, 地面を含まない地面上の物体のみを含むため，物体の発見 が容易となる性質を持っている。また残り半分はHVC の前

\footnotetext{
岐阜大学工学部

干501-1193 岐阜県岐阜市柳戸 1-1

Faculty of Engineering, Gifu University

1-1 Yanagido Gifu, Gifu 501-1193
}

方を映した直接画像で, 地面と物体の両方を含み, 2 つの画 像の境界線が地平線となる。そのため一般的な物体検出で は地面と物体の区別を必要とするが，HVCを用いることで その処理は不要となり, 正確に物体を発見できる利点を持 っている。

ここでHVC の性質を詳しく表現すると, 物体の接地点か ら上のみを映した画像が獲得可能となる。つまり物体の接 地点となる地平線付近のみを観察することで, 物体の地面 への接触, 非接触を検出可能であるという新たな性質が得 られる。また同時に得られる直接画像からは, 地面に接触 している物体の位置が計測できる。これにより, 先に述べ たカメラを用いた入力インターフェースを実現する際に重 要な, 位置計測と平面への接触検出という 2 つが，HVCを 用いれば同時に可能となる。

そこで本稿では，この HVCの性質を用いた新しい入力イ ンターフェースを提案する。これまで我々は, 物体検出の ために HVC の動画的性質を用いてきたが, HVC の静止画 的性質に着目することで, 反射画像にて平面に対する物体 の接触, 非接触を調べるタッチセンサーと同様の機能と, 直接画像にて物体の接触位置の計測機能を持った新しい入 カインターフェースの実現を可能にした。

本稿では，まず HVC の概要について述べ，HVC が持つ 性質の新しい利用方法について提案する。そして, 入力イ ンターフェースの一例として「どこでもピアノ」を作成し， 
実験により本提案システムにおけるタッチセンサーとして の精度を調べることで，新しい汎用入力インターフェース が構築できることを示す。

\section{Horizon View Camera と物体検出}

〈2·1〉 Horizon View Camera まず, HVC の概要を 説明する。一般的に，壁面を含む地面上に存在する全ての 物体を検出対象としたとき, 検出対象外は地面や床に相当 する。そのため物体検出を行うには，この場合の背景にあ たる地面領域から物体を高い精度で分離する必要がある が, 最も問題となるのは, 抽出した物体の地面からの識別, 切り出しであると考える ${ }^{(7)}$ 。これらの問題を簡単にするため に，カメラ位置を工夫したり，距離情報などを用いる場合 も多い。さらに単眼カメラでの位置計測では，一般的に物 体は地面に垂直に立っているものと考えて, 得られた物体 領域の接地点の座標值とカメラ情報を用いて, 物体の位置 を計測する。しかしこの物体の位置計測法は，物体領域の 抽出を正確に行えない場合は, 精度の高い位置計測は不可 能である。つまり精度の高い物体検出を行うには, 地面領 域と物体領域を高い精度で分離が可能な方法が必要とな る。

そこで，我々は従来の物体検出法とまったく逆の考え方 を用いたカメラシステムを作成した。一般的な単眼カメラ による物体検出では，精度を上げるために，カメラをより 上方に置き, 地面とカメラ光軸の成す角度を大きくする傾

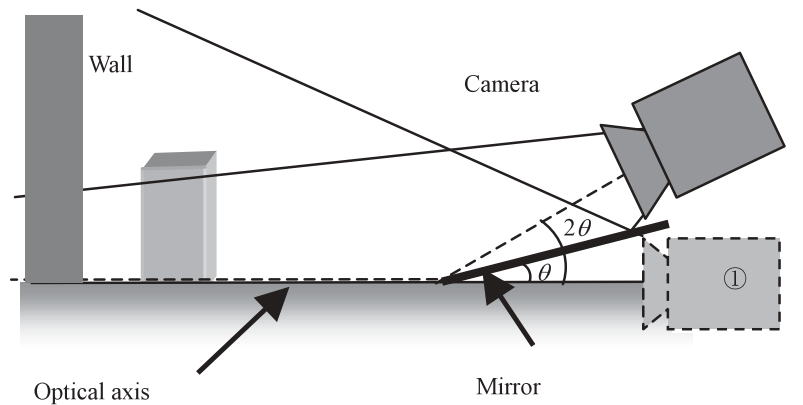

図 1 HVC システム

Fig. 1. HVC system.

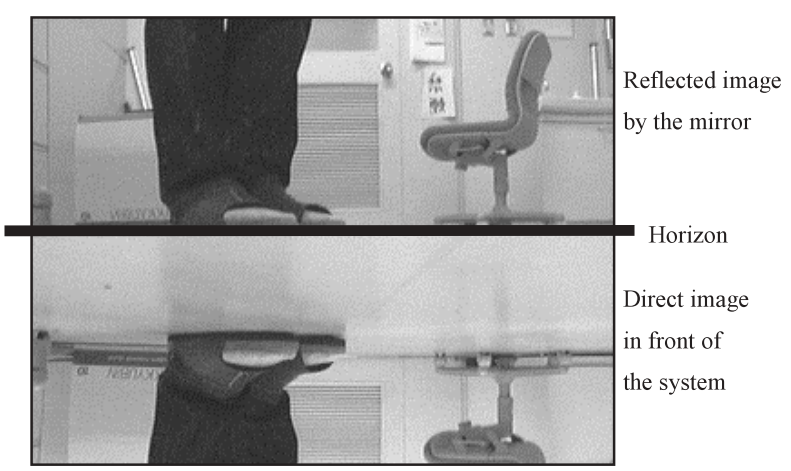

図 2 HVC から得られた画像

Fig. 2. Image from HVC.
向がある。しかし本システムはそれとは逆に下の方に設置 し, 地面とカメラ光軸の成す角度を 0 度にする, つまり地 面につけるように設置する。そうすることで, カメラ位置 が非常に低いため地面が見えない, 寸なわち地面領域を含 まず，周囲にある地面上の物体のみの画像が得られると考 えた。これを実現するために, カメラを地面近くに設置し, カメラの光軸が地平線上を通るようにシステムを作成し た。これをHorizon View Camera（以下，HVC）と名付けた。

〈2.2〉 HVC の構成と物体検出方法 カメラの光軸が 地平線を通るようにするには, 図 1 の(1)に示すように, カ メラの下半分を地面に埋める必要があるが，これは実際に は実現が難しい。そこで鏡を用いて，カメラの光軸が地面 上を通るようにシステムを設計した ${ }^{(8)(9)}$ 。HVC システムを図 1 の(2)に示す。ここで, カメラの光軸を地面上に通すために, 地面と鏡との角度と, 鏡とカメラの光軸との角度を同じに する必要がある。得られた画像のうち, 半分は鏡の反射に より得られた画像（以下, 反射画像）で, 残りの半分は鏡 の前方の画像（以下，直接画像）である。この 2 つの境界 が地平線となる。HVC から得られた画像を図 2 に示す。図 2 において，本稿ではより分かりや寸く表示するために，力 メラを通常とは上下を逆に設置した。そのため, 上半分が 鏡の反射画像となり, また下半分がシステム前方の直接画 像となっている。以下, 画像はす心゙てカメラの上下を逆に 設置して得られた画像である。

HVC が持つ性質には, HVC の前方にある物体のみの画像 が得られることが挙げられる。また HVC が前進移動するこ とにより発生するオプティカルフローは, 画像中心から外 一向かって流れる。この 2 つの性質を用いることで, 物体 までの距離計測が可能である。 HVC の前進移動量やカメラ パラメータが既知であることより，オプティカルフローの 各移動ベクトルを用いて三角測量により物体までの距離計 測を行うことで物体検出を実現した ${ }^{(10)}$ 。

さらに, HVC が多様に動いた場合でも物体検出が可能と なる, Horizon View Camera-90（以下，HVC-90）を提案し, その有効性を示してきた ${ }^{(11)}$ 。

\section{3. 新しい汎用入カインターフェースの提案}

HVC は大きく分けて 2 種類の性質を持っている。一方は 静止している HVCから得られる画像が持つ静止画的性質で あり，もう一方は HVC が地面上を移動している際に得られ る画像が持つ動画的性質である(6)。どちらもこれまでのカメ ラシステムになかった新しい性質である。我々はこれまで, 物体検出を目的として HVC や HVC-90 の開発を行ってき た。これら HVCやHVC-90 において，いずれも HVC を移 動させて得られる画像が持つ動画的性質を用いた物体検出 方法についての研究を行ってきたが, HVCのもう一つの重 要な性質である静止画的性質の主な活用はしてこなかっ た。そこでHVCの静止画的性質について再考し, その性質 を生かすことで，これまでにない入力インターフェースを 考案した。 


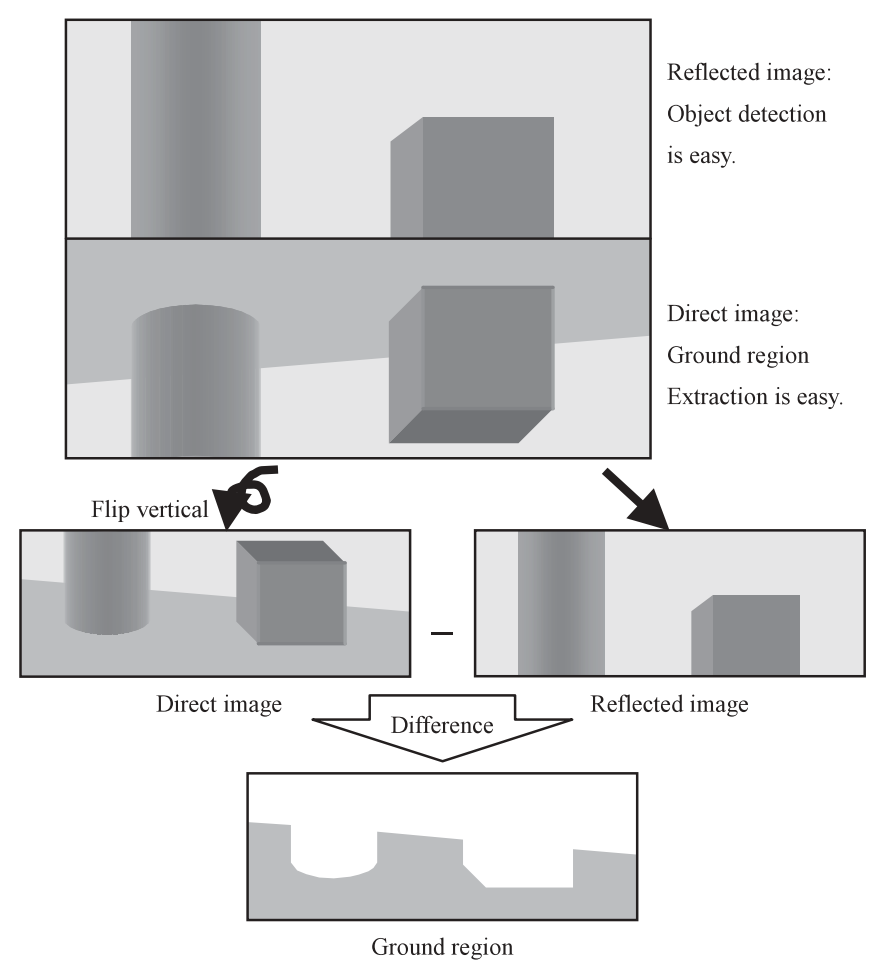

図 3 HVC の静止画的性質

Fig. 3. Static characteristics of HVC.

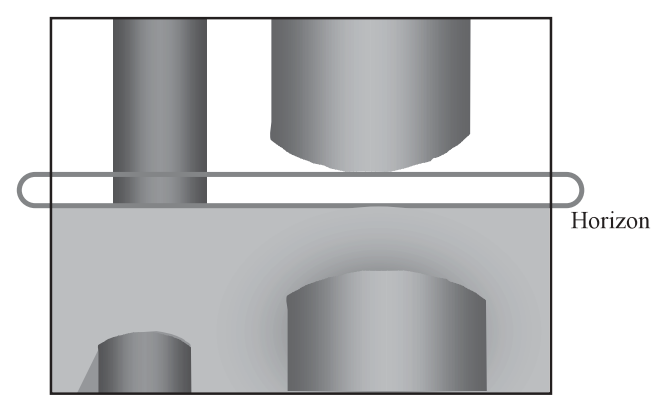

図 4 HVC によるタッチ検出

Fig. 4. Touch detection by HVC.

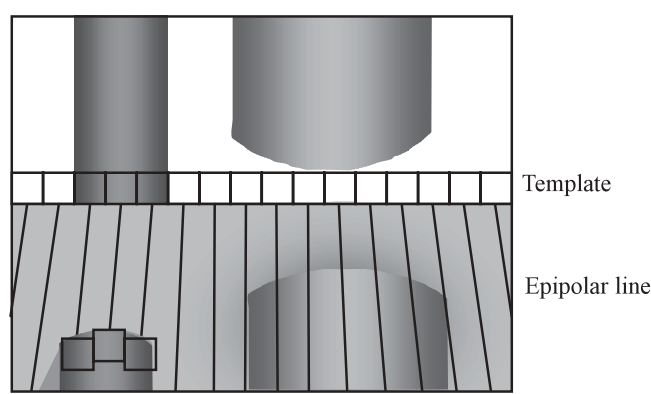

Boundary between ground and object

図 5 HVCのエピポーラ線

Fig. 5. Epipolar lines of HVC.

線付近を観察することで，物体が地平線に接触しているか を検出することが可能で，タッチセンサーと同樣の機能を 持つという新たな性質が得られる。図 4 において直接画像 では物体の地面への接触検出はできないが，反射画像の地 平線付近を調べることで, 物体が地面へ接触しているかを 容易に検出できる。

さらに, HVC はカメラ光軸を地面上に無限に走らせてい るため, タッチセンサー機能の範囲は画像に映し出された 領域全てとなる。また上記の反射画像と直接画像による連 携的性質により, 画像の差分から地面領域の抽出が可能で あるが, カメラパラメータが既知であることから, より容 易に地面領域が抽出できる。まず反射画像における物体の 接地点部分でテンプレートを作成し，図５のようにエピポ 一ラ線に沿って直接画像を探索してマッチングする部分を 検出する。マッチング位置は物体の接地点であるため, 物 体と地面の境界線とすることができ，地面領域を抽出した こととなる ${ }^{(6)}$ ここの直接画像における地面領域抽出は, 物体 の接地点が求められるため, その座標値から三角測量によ り物体の位置計測が可能となる。

すなわち，今回得られた HVCの新たな性質を用いること で，HVC をある平面に設置した際に，反射画像で平面に対 するタッチセンサー機能を，そして直接画像も用いること で平面に接触した位置計測を可能とする, 新しい入力イン ターフェースが実現できる。これまで HVC は物体検出を目 的としたシステムであったが，HVC の性質を別の角度から 見直すことで，同じカメラシステムのままであるが，入力 
インターフェースという全く別の目的に対応したシステム となった。

\section{4. どこでもピアノ}

〈4·1〉 どこでもピアノの概要ＨVC の性質である， タッチセンサー機能と位置計測を用いた入力インターフェ 一スとして様々なものが考えられるが，本稿ではその一例 として“どこでもピアノ”を作成した。どこでもピアノの 概観を図 6 に示寸。カメラの画角や鍵盤の大きさ $(5.2 \mathrm{~cm} \times$ $7.0 \mathrm{~cm}$ ）を考慮して，今回の鏡とカメラを構成する角度 $\theta$ を 約 15 度にした。また HVC から得られた画像を図 7 に示す。 図 6 に示すようにどこでもピアノでは，地面は鍵盤が描か れているボードに相当し, ボードに接触する物体はユーザ ーインターフェースとして人間の指とした。そして指が鍵 盤に接触した際にその接触と接触位置を検出して，接触し た鍵盤の音を出すことでピアノ演奏が可能なシステムを構 築した。よってカメラ, 鏡, 紙 1 枚でピアノ機能が実現可 能である。

〈4·2〉 どこでもピアノ実現方法ＨVCによる入力イ ンターフェースを実現するために，2 つの方法が挙げられ

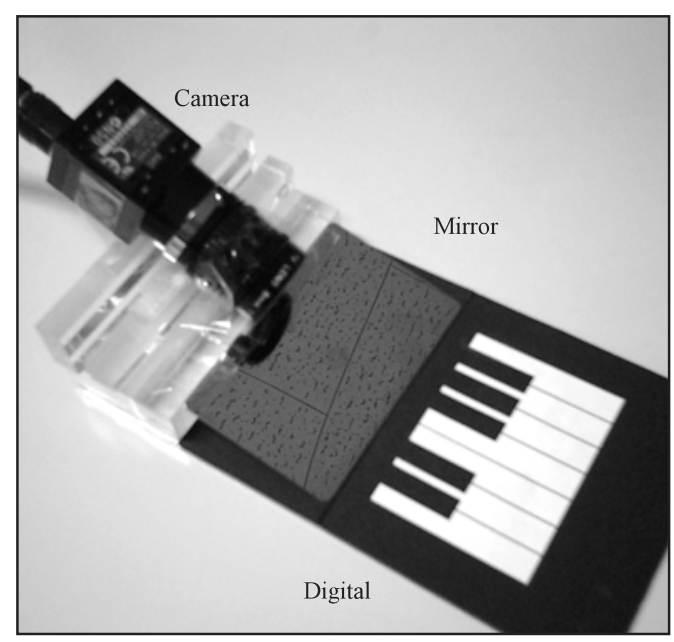

図 6 どこでもピアノ

Fig. 6. Portable piano.

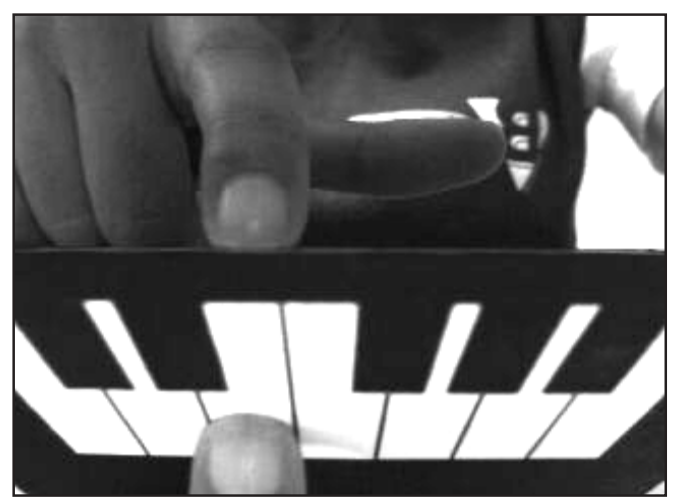

図 7 どこでもピアノの画像

Fig. 7. Image from portable piano.
る。

一方は反射画像の情報を直接画像で利用寸る方法であ る。図 8 に示すように, まず指のボードへの接触を調べる ために反射画像の地平線付近を観察する。そして指が地平 線に接触したと検出された後, 反射画像と同じ指を直接画 像にてエピポーラ線に沿って探索, 発見し, その座標值に より接触位置を計測する方法である。この方法の利点は, 指の接触を観察するためには, 常に反射画像の地平線付近 のごく狭い範囲のみでの指検出処理となり, また接触した 場合には, 直接画像におけるその指の探索が必要な部分は エピポーラ線上として限定できるので, 画像処理範囲が狭 く, 処理コストの軽減が可能である。しかし, 反射画像は 通常ユーザーとその背後を含んだ複雑背景画像である場合 が想定されるため, 地平線付近のみの観察ではあるが，指 と複雑背景を分割するための処理が必要となり，常に高い 精度で検出するのは難しい。

もう一つの手法は, 図 9 に示寸ように直接画像から反射 画像へ処理する方法である。ボードに対して HVC は固定で あることから，指を含まない状態での直接画像は常に一定 となる。そこで背景差分等を用いることにより直接画像中 に現れた指領域とその座標值を求めることができる。次に エピポーラ線から, 指がボードに接触した場合には反射画 像中における指が存在しているであろう場所が，地平線の すぐ上に一点として求まるため, そこに同じ指があるかを 調べることで，その指のボードへの接触が判定可能である。

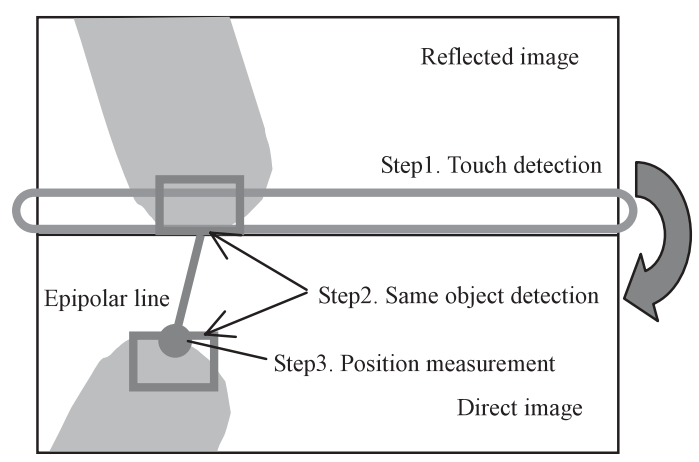

図 8 入力インターフェース手法 1

Fig. 8. Method 1 of input interface.

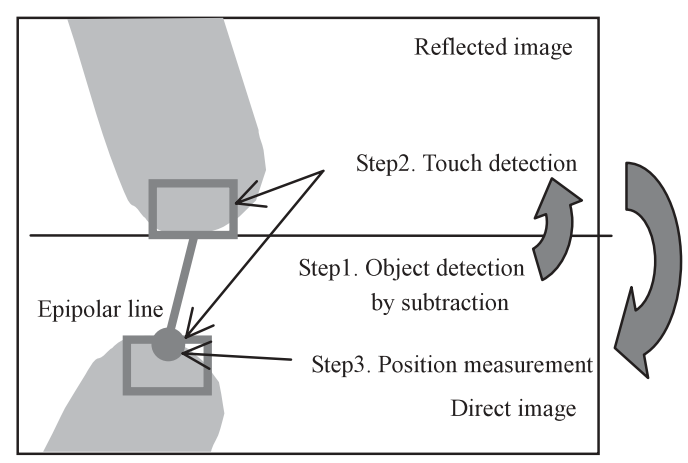

図 9 入力インターフェース手法 2

Fig. 9. Method 2 of input interface. 


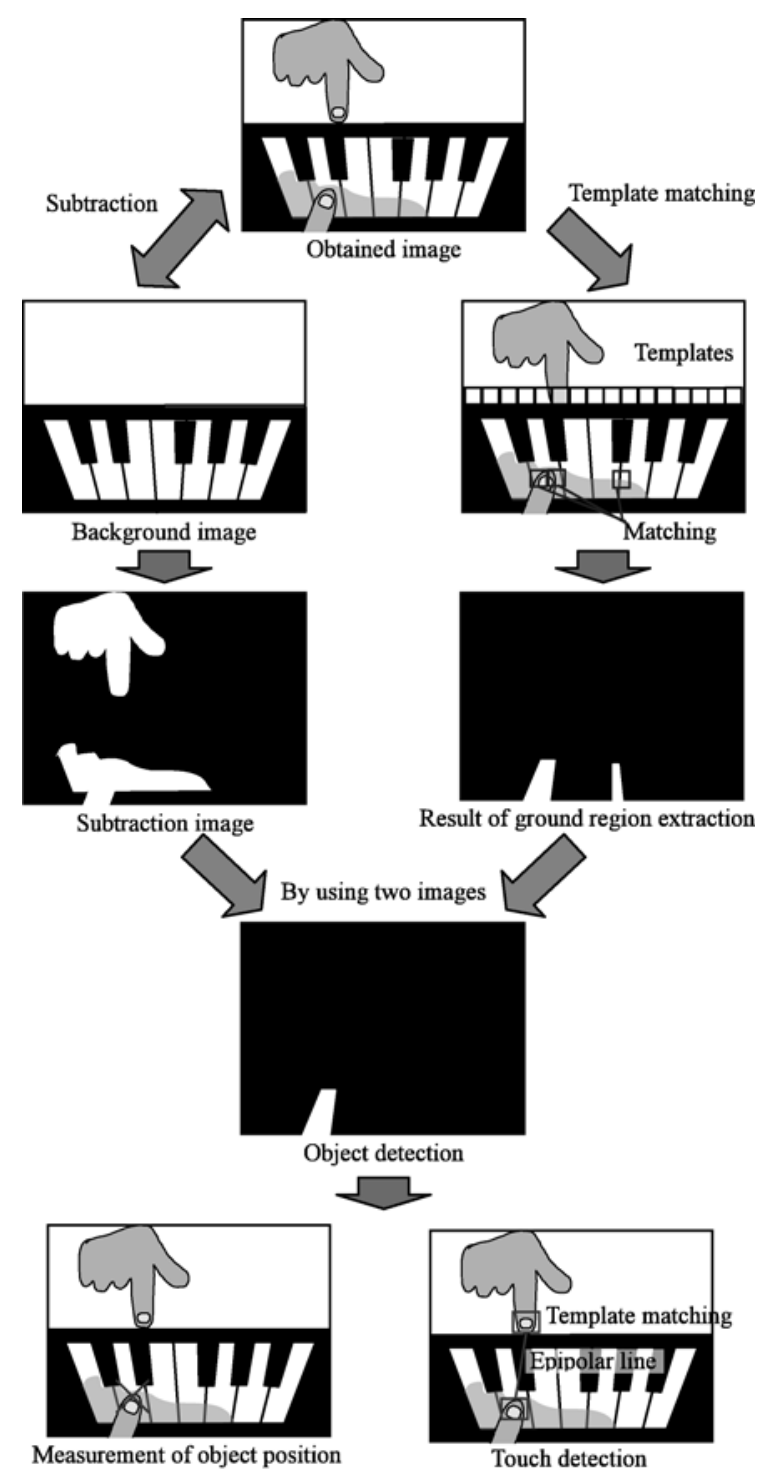

図 10 画像処理の流れ

Fig. 10. Flow of image processing.

そして指が接触したとき、座標值から接触位置を計測する。 先の方法に比べて画像処理範囲は直接画像全体と反射画像 の一部と広くなる。しかし, 指領域検出に用いる直接画像 の背景は予測可能であり, 反射画像での接触検出の際も工 ピポーラ線を用いることで 1 つの指領域に対して一点だけ の処理にとどまるため，あらゆる環境で精度の高い動作が 期待できる。

そこで本稿では，システムの動作中に状態が変化した場 合でも，信頼性の高い入力インターフェースが実現できる， 後者の方法を用いてどこでもピアノを作成した。

〈4·3〉処理の流れ どこでもピアノを実現するには, ユーザーの指の検出とその接触判定, そして接触した位置 計測によって音の発生や音階を決定する必要がある。

まずは直接画像を用いて背景差分により指領域を検出す る。しかし光源の位置や指や手の影などの影響により，検 出対象の指領域以外の部分を指領域として検出する可能性
があり，単純な背景差分だけでは精度の高い指抽出は困難 である。そこで検出対象である指領域以外の部分を消去す るために，3 章で述べた地面領域抽出手法を適用した ${ }^{(6)}$ 。こ れは反射画像の地平線付近でテンプレートを作成し, 直接 画像でエピポーラ線に沿って探索することで, 検出対象物 体にはマッチングするが，検出対象物体以外の部分はテン プレートとは異なるためマッチングしない。つまり指領域 は検出されるが，指の影などの検出を回避することができ る。理論的にはこの手法だけで指検出は可能であるが，実 際はテンプレートマッチングの失敗等で正確に地面領域を 抽出できない場合がある。どこでもピアノを実現するため には, 接地点座標值は指先の頂点と横幅の中点から求める ため, 指先領域を正確に検出する必要がある。そこで背景 差分と地面領域抽出の両方を用いることで, より正確な指 領域検出を目指した。よって地面領域抽出手法と併用する ことで, 背景差分で検出される指領域以外を除くことが可 能となる。そして得られた指領域とボードとの境界部分で 指テンプレートを作成し, 反射画像にてエピポーラ線から 求められた 1 点でマッチングすることで, その類似度から 指がボードに接触しているかを判定する。接触と判定され れば，直接画像から得られた指領域の座標值により，三角 測量にて接地点の位置計測を行う。この処理の流れを図 10 に示す。位置計測式を式(1)，(2)に示す。式(1), (2)において, 画像サイズ $W \times H$ とした場合, $(x, y)$ は直接画像中の指領域 の座標值, $P$ はカメラパラメータ, $h$ はカメラの高さ, $\theta$ は 鏡の成す角度, $D_{y}, D_{x}$ はカメラからの位置である。なお, 今回カメラパラメータの歪みは考慮していない。

$$
D_{y}=\frac{h\left(f_{22}+\left(y-\frac{H}{2}-f_{23}\right) \tan 2 \theta\right)}{f_{22} \tan 2 \theta-\left(y-\frac{H}{2}-f_{23}\right)}
$$

$$
\begin{aligned}
& D_{x}=\frac{D_{y}\left(x-\frac{W}{2}-f_{13}\right) \sqrt{f_{22}^{2}+\left(y-\frac{H}{2}-f_{23}\right)^{2}}}{f_{11}\left(f_{22} \cos 2 \theta+\left(y-\frac{H}{2}-f_{23}\right) \sin 2 \theta\right)} . \\
& \text { ただし, } P=\left(\begin{array}{cccc}
f_{11} & 0 & f_{13} & 0 \\
0 & f_{22} & f_{23} & 0 \\
0 & 0 & 1 & 0
\end{array}\right)
\end{aligned}
$$

\section{5. 実 験}

実際にHVC を用いたどこでもピアノを作成し, 得られた 画像から, 本システムの有効性を確認するため, 基礎実験 として位置計測精度について調べた。

実験に用いた画像は $320 \times 240$ pixel である。また地面領域 抽出のテンプレートサイズは $11 \times 15$ pixel, 接触判定となる 指のテンプレートサイズは $25 \times 11$ pixel とした。これらのテ ンプレートサイズは, ボードとの境界線や指を確実に獲得 できるように最適に設定した。ただし, 実用化を考慮した 場合, これらの值の設定方法は考察が必要である。本実験 では, まず前処理として背景画像, 入力画像の両者にガウ 


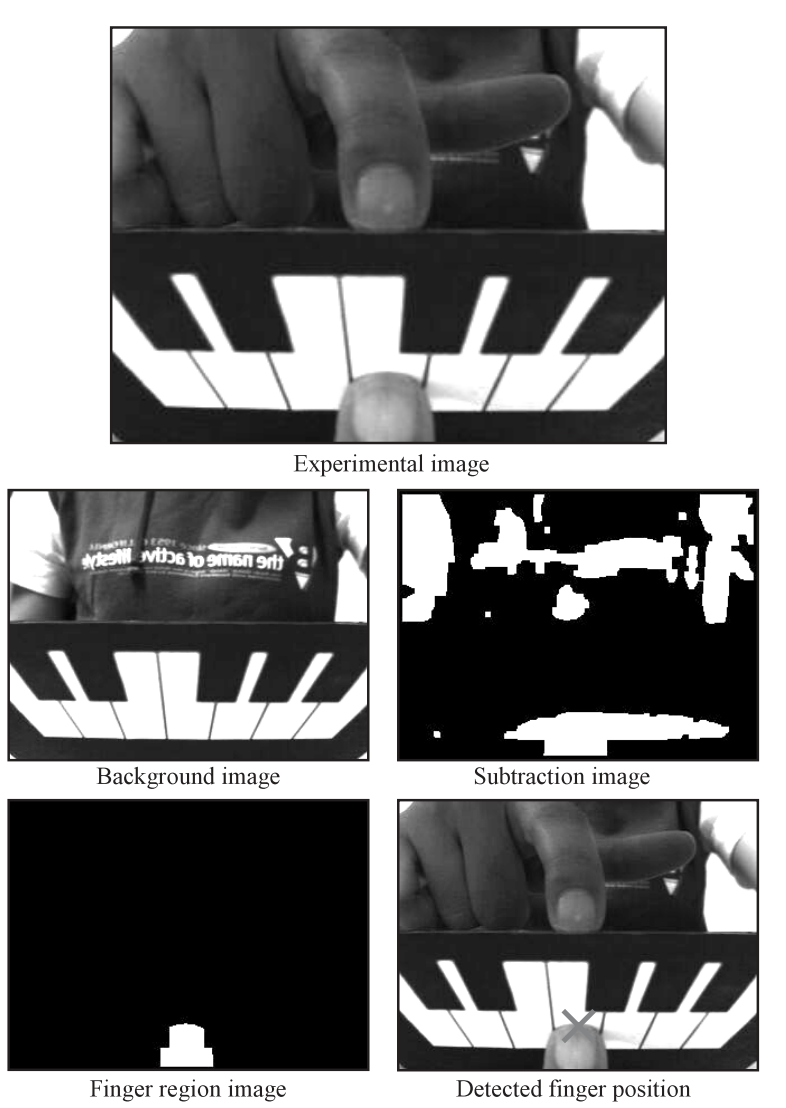

図 11 実験画像例

Fig. 11. Example of experimental image.

表 1 実験結果

Table 1. Experimental result.

\begin{tabular}{|c|c|c|c|c|}
\hline \multirow{2}{*}{} & \multicolumn{2}{|c}{$\begin{array}{c}\text { Result of position } \\
\text { measurement }\end{array}$} & \multicolumn{2}{c|}{ Answer } \\
\cline { 2 - 5 } & $D_{x}$ & $D_{y}$ & $D_{x}$ & $D_{y}$ \\
\hline 1 & $-3.26 \mathrm{~cm}$ & $9.27 \mathrm{~cm}$ & $-3.3 \mathrm{~cm}$ & $9.5 \mathrm{~cm}$ \\
\hline 2 & $-2.26 \mathrm{~cm}$ & $9.41 \mathrm{~cm}$ & $-2.3 \mathrm{~cm}$ & $9.5 \mathrm{~cm}$ \\
\hline 3 & $-1.34 \mathrm{~cm}$ & $9.41 \mathrm{~cm}$ & $-1.3 \mathrm{~cm}$ & $9.5 \mathrm{~cm}$ \\
\hline 4 & $-0.31 \mathrm{~cm}$ & $9.48 \mathrm{~cm}$ & $-0.3 \mathrm{~cm}$ & $9.5 \mathrm{~cm}$ \\
\hline 5 & $0.74 \mathrm{~cm}$ & $9.48 \mathrm{~cm}$ & $0.7 \mathrm{~cm}$ & $9.5 \mathrm{~cm}$ \\
\hline 6 & $1.73 \mathrm{~cm}$ & $9.48 \mathrm{~cm}$ & $1.7 \mathrm{~cm}$ & $9.5 \mathrm{~cm}$ \\
\hline 7 & $2.64 \mathrm{~cm}$ & $9.41 \mathrm{~cm}$ & $2.7 \mathrm{~cm}$ & $9.5 \mathrm{~cm}$ \\
\hline 8 & $-2.71 \mathrm{~cm}$ & $7.61 \mathrm{~cm}$ & $-2.8 \mathrm{~cm}$ & $7.5 \mathrm{~cm}$ \\
\hline 9 & $-1.69 \mathrm{~cm}$ & $7.51 \mathrm{~cm}$ & $-1.8 \mathrm{~cm}$ & $7.5 \mathrm{~cm}$ \\
\hline 10 & $0.43 \mathrm{~cm}$ & $7.66 \mathrm{~cm}$ & $0.2 \mathrm{~cm}$ & $7.5 \mathrm{~cm}$ \\
\hline 11 & $1.40 \mathrm{~cm}$ & $7.56 \mathrm{~cm}$ & $1.2 \mathrm{~cm}$ & $7.5 \mathrm{~cm}$ \\
\hline 12 & $2.33 \mathrm{~cm}$ & $7.66 \mathrm{~cm}$ & $2.2 \mathrm{~cm}$ & $7.5 \mathrm{~cm}$ \\
\hline
\end{tabular}

シャンフィルタをかけ, その後背景差分を行い, 雑音除去 のために膨張収縮処理を行った。そして地面領域を抽出す るが，その際には背景差分結果において差分がなかった部 分は必ず地面と考えられるため, その領域にフラグを立て た。そしてフラグのない部分で地面領域抽出を行うことで,

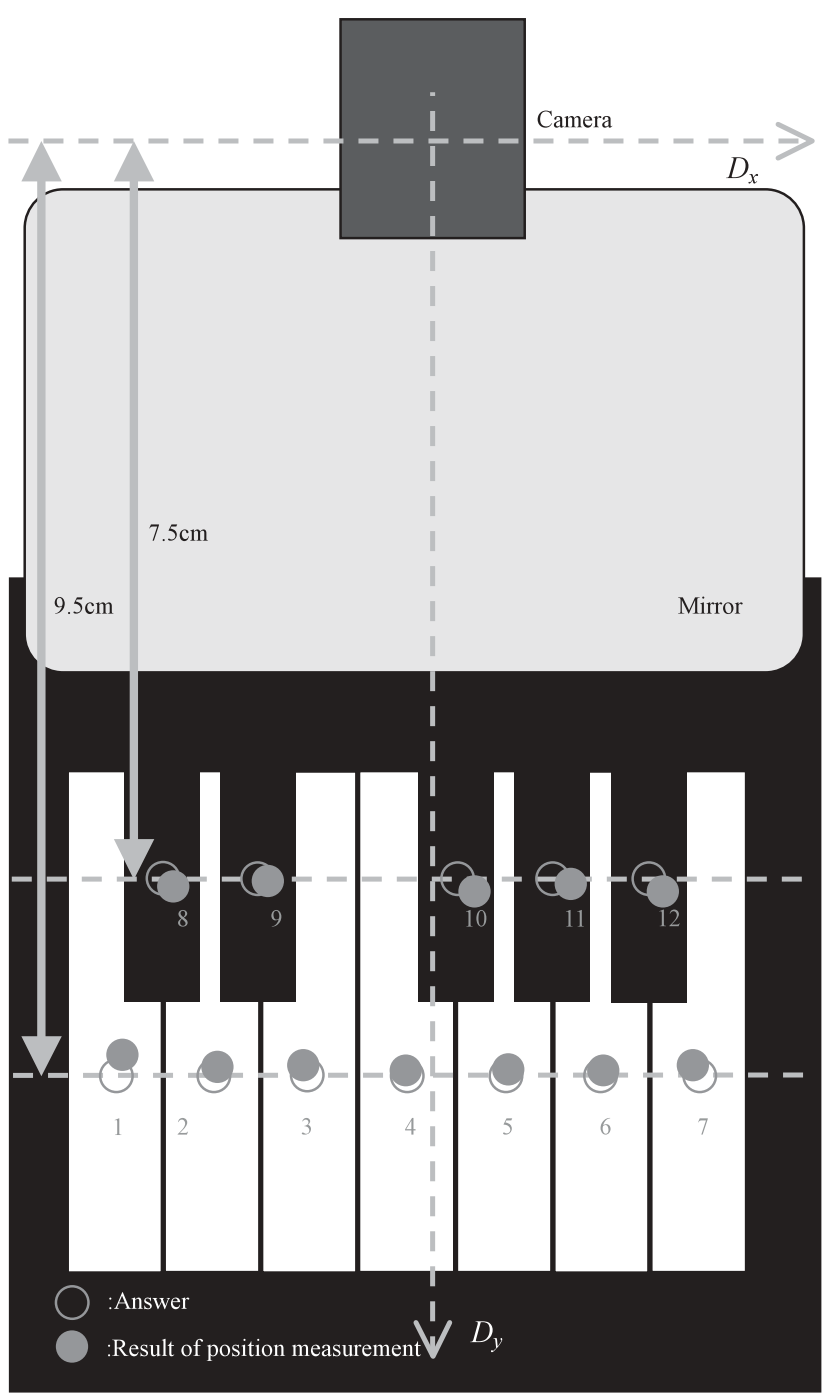

図 12 正解值と計測值

Fig. 12. Answer and measurement result.

計算コストの削減や抽出精度の向上を図った。ここで本稿 では，ノイズによるマッチングミスを防ぐために地面領域 抽出結果の座標值にメディアンフィルタを行った。

次に, 得られた地面領域を指領域とし, その上端を指の 先端, つまり地面との接地点とした。そしてその部分をテ ンプレートとしてマッチングを行い，接触判定を行った。 そして指の座標值から, 三角測量にて位置計測した。実験 画像と, その画像に対する実際の画像処理結果を図 11 に示 す。

実験データは，ピアノの 1 オクターブ分の鍵盤 12 箇所を 指で押して得られた 12 枚の画像である。それぞれの画像か ら指検出, 接触判別, 接触位置計測を行った。ピアノ 1 オ クターブ分の鍵盤 12 箇所における実際の位置と, 画像によ り得られた計測結果を表 1 に示す。また正解值と計測值を 比較した結果を図 12 に示す。なお正解值は, $D_{x}$ については 画像中心を基準にして求め, $D_{y}$ はカメラから $7.5 \mathrm{~cm}$, なら びに $9.5 \mathrm{~cm}$ とし，手動により各点を設定した。

$D_{x}$ 軸の位置計測結果の誤差平均は $0.085 \mathrm{~cm}, D_{y}$ 軸の位置 
計測結果の誤差平均は $0.088 \mathrm{~cm}$ となった。これらの誤差は, どこでもピアノを実現するには十分な精度である。また今 回求めたカメラパラメータにおいて, レンズ歪みについて 考慮しなかった。このため, 歪みパラメータを適用するこ とでさらに精度の向上が可能と考えられる。

\section{6. まとめ}

本稿では，HVC を用いた新たな入力インターフェースを 提案し, その優位性について示した。また入力インターフ ェースの一例としてあらゆる状態に対応可能などこでもピ アノを作成し, 実験によりタッチセンサーとしての精度を 確認することで，どこでもピアノが十分に実現可能である との知見が得られ, 試作によって入力インターフェースと しての実現可能性を示した。よって, 従来は物体検出を目 的として HVC の開発を行っていたが, 観点を変えることで これまでとは異なる入力インターフェースを目的としたシ ステムへと，HVCを拡張することができた。

また本稿で提案した接触検出, 物体検出方法は, HVC の 性質を生かしたことで, 容易かつ正確な入力インターフェ ースの実現を可能とした。さらに本手法では, 背景差分と HVC 特有の地面領域抽出の両方を適用することで, 環境の 変化に強いシステムとなった。これにより, 実験画像のよ うに白と黒の両極端の環境を含んだ背景に対応した入力イ ンターフェースが実現できた。

今回はHVCを用いた入力インターフェースの一例として どこでもピアノを作成したが，本手法は文字入力キーボー ドやマウス, タッチパネルなど, 多様な汎用入力インター フェースに応用可能である。しかし汎用入力インターフェ 一スの種類によっては, さらに高い精度が必要となると考 えられる。そこで今後, 精度向上のためにレンズ歪みの考 慮をはじめ, HVC のカメラの高さや角度, 画像処理におけ る各パラメータの考察, テンプレートマッチングの改良を 含む検出精度の向上が必要である。

(平成 16 年 10 月 26 日受付, 平成 17 年 4 月 21 日再受付)

\section{文献}

(1) Neil R. N. Enns, and I. Scott MacKenzie : "Touchpad-based-based Remote Control Devices", Proc. of the ACM Conference on Human Factors in Computing Systems - CHI '98, pp.336-343 (1998)

(2) http://www.canesta.com/products.htm

(3) Y.Nakanishi, K.Oka, M.Kuramochi, S.Matsukawa, Y.Sato, and H.Koike "Narrative Hand: applying a fast finger-tracking system for media art", Proc. of ISEA2002 (2002)

(4) J. Crowley, F. Berard, and J. Coutaz : "Finger Tracking as an Input Device for Augmented Reality, Proc. of Automatic Face and Gesture Recognition (FG'95), pp.195-200 (1995)

(5) M. E. Munich and P. Perona : "Visual Input for Pen-Based Computers", IEEE Trans. PAMI, Vol.24, No.3, pp.313-328 (2002)

(6) A.Iwata, K.Kato, and K.Yamamoto : "Properties of Horizon View Camera with the Optical Axis of the Camera on the Ground and its Implementation", Journal of ITE, Vol.58, No.9 pp.1291-1298 (2004-9) (in Japanese)
岩田彩見・加藤邦人・山本和彦 :「カメラの光軸と地面を一致させた Horizon View Camera の光学特性とその実現」, 映像情報メディア学 誌, Vol.58, No.9, pp.1291-1298 (2004-9)

(7) G.N.DeSouza and A.C.Kak : "Vision for Mobile Robot Navigation: A Survey", IEEE, Trans. PAMI, Vol.24, No.2 pp.237-267 (2002)

(8) S.Kaneko and T.Honda : "Calculation of Position of Polyhedral Objects Using Direct and Mirror image", Journal of JSPE, Vol.52, No.1 pp.149-155 (1986-1) (in Japanese)

金子俊一・本多康悟 :「直接像及び鏡像を利用した多面体対象物の位 置計算」, 精密工学誌, 52, 1, pp.149-155 (1986-1)

(9) J.Gluckman and S.K.Nayar : "Rectified Catadioptric Stereo Sensors", IEEE, Trans. PAMI, Vol.24, No.2, pp.224-236 (2002)

(10) B.K.P.Horn and B.G.Schunk : "Determining optical flow", Artificial Intelligence, Vol.17, pp.185-203 (1981)

(11) A.Iwata, K.Kato, and K. Yamamoto : "A Proposal of the Horizon View Camera-90 Using the Cooperation of Image on Orthogonal Camera System", Journal of IEEJ Trans. EIS, Vol.23, No.12, pp.2085-2093 (2003-12) (in Japanese)

岩田彩見・加藤邦人・山本和彦 :「直交カメラ系画像の協調を利用し た Horizon View Camera-90 の提案」, 電学論 C, 123, 12, pp.2085-2093 (2003-12)

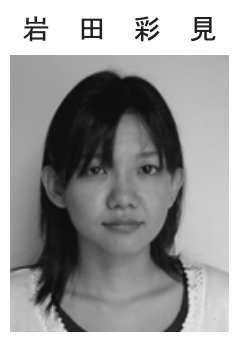

（非正員） 1978 年 4 月 2 日生。 2003 年 3 月岐 阜大学大学院工学研究科応用情報学博士前期 課程修了。現在, 同大学院工学研究科電子情報 システム工学専攻博士後期課程在学中。コンピ ユータビジョンの研究に従事。

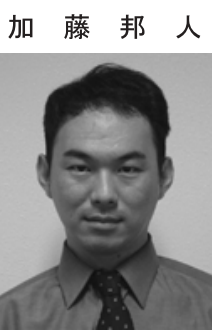

（非正員） 1971 年 2 月 18 日生。1998 年 3 月中 京大学大学院情報科学研究科修士課程修了。同 年, 同大学院博士課程。現在, 岐阜大学工学部 助手。画像処理, 特に Hough 変換による直線検 出とその応用の研究に従事。情報科学博士。

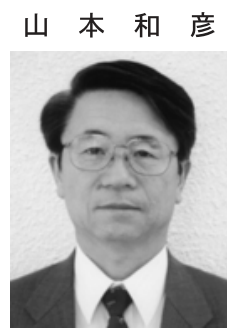

（正員） 1944 年 6 月 20 日生。1971 年 3 月東京 電機大学大学院修士課程修了。同年, 通産省電 子技術総合研究所入所。1986 年同研究所知能情 報部画像研究室室長。1 995 年から現在, 岐阜大 学工学部応用情報学科教授。主に画像解析, パ ターン認識の研究に従事。IAPR, 電子情報通信 学会フェロー。工博。 